\title{
Consumer-Band Association: Determinants of Consumer Bank Switching Intention, Case of the Gambia Retail Banking Sector
}

Lamin B Ceesay*

Faculty of Economics, Vilnius University, Lithuania

\begin{abstract}
Consumers develop brand knowledge based on their opinion of brand or information to infer meanings to the company and its products and services. Studies showed that associations that are deep-seated in the memory affect consumer behavior toward the company or its brand. Switching behavior has become quite unprecedented among consumers in retail banking sector of The Gambia and several reasons accounts for this practice. Results of Pearson correlation statistics showed that there is a significant negative relation between customer brand perception (price perception, corporate image, customer satisfaction, quality of services and trust) and intention to switch banks.
\end{abstract}

Keywords: Brand associations; Trust; Pricing; Celebrity endorsement; Switching intention

\section{Introduction}

Branding is attracting growing interest as a result of the important role it plays in global trade. Notable authorities of brand of management have confirmed that branding is a source of competitive advantage, means for distinctiveness [1,2] and a tool for building longterm profitable relation between the organization and its stakeholders [3]. While significant studies concentrated on product branding due to its tangibility attributes, researchers and practitioners are diversifying attention toward exploring the potentials of service branding. Today's global business operation is predominantly services-centered and thus requires the need to communicate with stakeholders through service brand offerings. This trend has taken a serious attention shift within the financial institutions in today's dynamic marketplace.

Branding in the financial institutions is one that requires relationship, trust and credence building [4], hence branding is critical in customers' choice of bank selection. Branding has become a strategic issue rather than just an operational activity in service-oriented businesses. According to Keller [5], one of the challenges in marketing services is that they are less tangible than physical products, and are more likely to vary in quality, depending on the provider or people offering them. For that reason, branding can be particularly important for banks as a way to address intangibility and variability problems $[3,6]$.

Despite the challenges, studies show that building strong and favorable service brands among consumers requires number of efforts in terms of delivering the right value proposition - as promised, consistently, expedite delivery process, courtesy and trust [3]. Hinson et al. noted that the emergence of internet and related technologies in the banking sector has made branding a strategic resource to access larger market areas while at the same time pose a serious challenge as customers are getting sophisticated in their demand for banking services. Brand is as valuable as the tangible assets of organizations. Keller [5] argues that building strong and favorable brand requires full commitment of managers and employees; thus, brand gives value by allowing the company to deliver the promise to the consumer. Furthermore, it is a whole collection of brand associations that accompany the value the brand promises. Aaker [1] notes that building strong brand equity is an endearing effort; hence it requires a holistic approach-outward looking, to design appropriate marketing programs that support the innate brand value. To do that, brand managers must integrate and manage all the brand touch points in order to ensure that consumers and other relevant parties develop positive associations with the brand [5,7].

Despite the significance of brand associations, especially in banking industry, there is limited empirical study that researches on the premise of this area - brand association and customer switching intentions - thus, leaving the field yet to be fully explored. However, the researches $[8,9]$ confirmed that there is a relationship between brand association and consumer behavior. These studies focused mainly on brand associations relevant to specific tangible products. According to Keller [5] brand associations are customer specific and thus vary across markets and brands. Also, a specific set of associations used in a given setting may not justify the same degree of influence and relevance to other markets and product category $[4,10,11]$.

The subject of branding financial services requires further empirical studies in order to explore what sort of information they transfer to brands, and how this knowledge influence switching intention of consumers of a bank. In order to fulfill these gaps, this research seeks to answer the problematic question - Consumer-brand association: determinants of consumer bank switching intention, case of retail banking sector of The Gambia? In order to provide answers to the research problem, the following objectives will guide the entire research:

- To analyze the theory of consumer-brand associations.

- To analyze brand switching behavior and consumer switching intention.

- To analyze specifics of brand switching in financial services.

- To analyze determinants of consumer switching behavior.

*Corresponding author: Lamin B Ceesay, Faculty of Economics, Vilnius University, Lithuania, Tel: +370 5268 7000; E-mail: ceesaylaminb@gmail.com

Received October 09, 2017; Accepted October 16, 2017; Published October 26, 2017

Citation: Ceesay LB (2017) Consumer-Band Association: Determinants of Consumer Bank Switching Intention, Case of the Gambia Retail Banking Sector. J Bus Fin Aff 6: 295. doi: 10.4172/2167-0234.1000295

Copyright: @ 2017 Ceesay LB. This is an open-access article distributed under the terms of the Creative Commons Attribution License, which permits unrestricted use, distribution, and reproduction in any medium, provided the original author and source are credited. 
- To formulate a hypothesized model of brand associations and switching intention based on the review of relevant literature.

There is unfortunately very limited study on consumer switching behavior in services, especially in retail banking sector. This study is thus organized first with a theoretical review of relevant scientific researches on brand associations, customer switching behavior, leading to the formulation of hypothesis of the study - showing a link between brand associations and consumer intention to switch banks. Second part of this work is the research methodology of questionnaire survey consisting two hundred and ten respondents from bank customers in The Gambia before presenting the results of the findings from data analysis. In the final part, the study is concluded with discussions of the findings, and highlights of some limitations of the study.

\section{Literature Review}

\section{Theory of brand associations}

Brand association is anything linked in the memory of consumer about the brand [1]. This association is related to the brand's node in the memory of customers in order to recall or recognize the brand under certain situations $[1,5,12,13]$. Furthermore, associations can be combinations of anything like a concept, feeling or personality customers infer to the brand name directly or indirectly [8].

Studies have it that managing brand equity is about building strong, favorable and unique brand associations in the mindset of consumers in order to invoke desired response [5,10]. Keller [2] has demonstrated that customer-based brand equity (CBBE) is a multidimensional construct which includes brand awareness, brand loyalty, brand image, and brand associations. Studies further adduce that the most important element of all CBBE is the association that consumers held about the brand in the memory $[10,14]$.

Managers should ensure that their brands are associated with something positive, one-of-a-kind and strong so that customers may associate positive thoughts, image [8] as well as good feelings about the brand in a given category or market [15]. By doing so, it creates a blueprint, and indelible mark in the memory of consumers. Therefore, brand associations are the basis for customer relationship, purchase decision and building brand loyalty [1]. Developing and creating programs that will enhance these associations and linking them to the brand node in the memory remains a challenge in brand management practice. Studies indicated that these set of associations constitute a fundamental basis in building strong brand awareness as "top of mind", and a source of company's 'brand mantra' for effective brand positioning $[10,16]$. Successful brand associations are the reasons behind customers' trust and behavioral intention to purchase a brand [14,17], and useful criteria in consumer repurchase decision making [8].

Customers generate perception of a brand based on a set of information in the memory obtained from variety of sources. This includes the marketing campaign, the product/services itself, social programs, being global, innovativeness, competitors' marketing activities, and so forth $[1,10,13]$. However, not all of these associations may be important to invoke immediate purchase behavior [7]. Each set of information held in the memory can be activated independently or correspond to another informational node depending on the buying situation [9]. Therefore, information that is held in the memory can be descriptive, visual or emotional, and are spirally linked to one another and activated either consciously or unconsciously under certain situation.
According to Supphellen [15], branding has a sharp focus on consumers by creating brand-related experiences that have potentials to invoke more sublime emotional and psychological impact on consumer memory. Therefore managers must fully understand potential associations that consumers may infer on their brand, such as pre-conscious or non-verbal connotations. Although gaining in-depth knowledge of brand association is a relentless challenge, but, it takes great effort to build a strong brand image and equity [3]. Studies are not limited to cognitive psychology alone, but as well as sociological orientations towards specific consumption and buying situations, and behavioral gestures like facial expressions have been well documented [15]. Therefore, customer perception of a brand under low involvement is vital to the overall brand image held in the memory. According to cognitive psychology, low involvement situation (situations or environment where a consumer is not faced with any form of hassle for alternatives or promotions) reduces emotional associations and constitutes the main determinant for choice of brand [15].

Aaker $[1,12]$ has formulated a renowned set of brand associations and categorized them into eleven: product attributes, intangibles, customer benefits, price, use/application, user, celebrity, lifestyle, product class, competitors, and country of origin. These associations are further grouped according to product-based associations relate to the main function or problem the brand is set out to solve, which includes the performance, value or price, uses and attributes. These constitute the basic determinant for the existence of the brand and how it relates to the needs and wants of customers. However, in today's dynamic marketplace, consumers demand more than brand's functional or core performance, but, as well as its emotional and sociological benefits it brings in relation to competition [10]. Therefore, marketers use several forms of activities in order to invoke certain emotions with consumers towards the brand. Organization-based associations explain perceptions customers may infer onto the brand about the company [10] based on its branch location, country of origin, the corporate name, reputation, policies, personnel, service delivery, [12] among a host other. These sources are vital in building trust and confidence with the company's overall stakeholders [11]. Commercial banks continue to invest heavily in this strategic area because its business requires security, confidence and quality of services [3]. The other category of brand association is personality attributes which expresses consumers' emotion and inherent personal attribute $[1,12]$. According to these studies, this is a component of brand marketing that lures customers to a brand because it relates to user imagery, self-expressive benefit, emotional benefits, and brand personality, and brand/customer relationship.

Keller [13] theorized brand knowledge based on brand associations and secondary associations. Secondary associations link other entities to the brand in consumer memory such as celebrity, distribution channels, country of origin, events, etc., while brand associations arise from the primary attributes of a brand in the memory such as design, color, price, user imagery, and image. Keller [5] further categorized them according to brand attributes, brand attitudes and brand benefits. Whereas brand attributes are the descriptive features of a brand (including both product and non-product related aspects on the brand) based on of what customers think of the brand. Brand attitudes explain the consumers' overall evolution of the brand thereby helpful in making a brand choice. Brand benefits constitute the value or the problem the brand is set to satisfy which can be functional (linked to the psychological needs), experiential (what it feels using the product) and symbolic (need for social approval or self-esteem). Additionally, associations from secondary sources like the company of the brand, brand country of origin, category association are useful 
to elicit customer's perception of the brand [1,5]. Studies proved that understanding the full breadth and length of brand association is crucial to strategic positioning and differentiation of the brand to occupy a distinct place in the memory [5,14]. Consumers can develop and reinforce memory for a specific brand relative to competitors based on experience and involvement [14]. However, a question of how much of this stored information can be retrieved and acted upon remained uncertain [18]

Customers can easily develop perception of tangible products from its visual contents like package style, colors used, brand names and several other disruptive and visual expressions attached the brand $[1,5,19]$. According these studies, these features augment the search, consumption and risk of the brand. Brand associations are not limited to only goods, but services as well and focusing on the company as the primary brand [3]. Branding in services is about building trust of customers' intangible purchase and thus reduces risks by leveraging the company name. Marketing techniques and tangible inducements during service encounters can also reinforce brand presence and positive associations in services brands [11]. Berry [3] adduce that customer's perception of service brand emanates from two sources: the customer service experience and the overall perception of the company. Therefore, trust and quality service are intimately linked and constitute the cornerstone for successful service brands $[3,20]$.

\section{Consumer opinion of brand associations}

Price perception: Price is consideration for what one pays in order to enjoy the benefit or service obtained from another. Price includes both financial and non-financial, perceived and real cost [12] involved in purchase and use of a product. According to Kapferer [7], it is a marketing mix element with a revenue stream to the business, and one of the most important decision factor for consumers. In banking, pricing is a key strategic issue and a source for sustainability and profitability [21].

In the study of customer switching behavior in Malaysia, Subramaniam and Ramachandran identify pricing in banking industry as implementation of fees, bank charges on transactions, interest levy on loans, interest on saving accounts and customer deposits. Additionally, on a broader spectrum of service companies, (e.g., banks), Keaveney and Parthasarathy identified pricing factors which include price, rates, charges, sub charges, penalties, price deals, price promotion and coupons [22]. These factors have significant influence on customer behavioral intention and overall perception of services, as well as financial service brands [22]. However, the question is to what extend can prove perception influence switching intention of consumers of financial services? This is because price has multidimensional effect on consumers [3].

Price forms an integral part of a brand's identity and thus, brand equity [2]. Therefore, customers form perception of a brand through its price which apparently is used by companies for numerous reasons in order to influence purchase behavior, assure quality products and services, and building desired image. Implementing cost saving and cost-cutting practices is part of efforts to avoid loss of money and thus promote profitability - making pricing very crucial strategic choice. However, Wruuck argued that price is not independent on its own, but rather it must be integrated into the overall corporate strategy for profitability and long-term customer satisfaction. In recent studies, more than $50 \%$ of the customers who defect or switch from one brand to the other attributed this behavior to price dissatisfaction [23-26]. Furthermore, Zeb et al. [26] showed that bank rate and interest charges influence switching behavior among youth and low income consumers. Therefore, bank's pricing policy constitutes the cause varying opinion among individual as well as corporate and other business clients [23]. To infer positive associations to with price, banks must keep up pricing as a strong measure of optimal service quality and at the same time build strong structural bond and trust with their clients [3,11].

Price significantly influences the overall customer purchase behavior in financial services sector [24]. Although, its influence may differ from one set of consumers to others, as well as one financial service to the other [27]. Consumers use price as measure of product or service quality, and meeting these expectations can promote satisfaction and loyalty [27]. It becomes a challenge to establish the right price (in terms of profitability, etc.) while at the same time promoting customer expectations (in terms of quality cues).

According to studies, to invoke customers' emotional appeal and influence their purchase intention, marketers must set brand's price base on "good value", one that is integrates with the value that the brand promises. In banking industry, customers are getting more pricesensitive, thus companies try to entice existing customers to remain loyal, and inducing prospective clients to switch from competitors through price promotion [22]. However, there are customers who are willing to have good price deal than the "right" brand. Farquhar and Panther [25] showed that competition based on lower differential price margin for a brand can stimulate purchase intention, but, a further price fall on other categories may induce switching behaviors among such consumers. Therefore, pricing from consumer perspective vary widely and differ in terms of influence across consumer demographics and product type [22].

Assumption can be made that there is a higher rate of bank switching among consumers when price or cost of banking operation rises. Dapkevicius and Melnikas posit that price perception bears a significant influence in customer satisfaction and loyalty. According to Manrai and Manrai [28], significant per cent of switching behavior is attributed to bank's high service charges and high interest rates on loan. Also, a small marginal increase in transaction cost causes a significant customers' bank switching in Pakistan [23]. Again, it can be noted that increase in bank charges causes bank switching among young-aged and less educated customers of New Zealand and Australian banks [6]. On the other hand, a study of bank switching in UK shows that when there is a strong relationship between the bank and its customers, increase in bank charges has insignificant influence on customer intention to switch [25]. Therefore, it is not clear whether there is a stronger congruence between customer price perception and switching intention in a case of a developing economy like The Gambia. It is thus supported that price rise affects consumers' purchasing decision in an economy with low GDP per capita thus limiting consumer purchasing power. Based on this assertion, the following hypothesis is formulated: H1. As customer's perception of price becomes unfavorably low towards a bank, the intention to switch to another bank increases.

Quality of service: de Charnatony and Harris [29] considers brand performance as a dependent variable and assert that customer satisfaction is key to defining and measuring brand performance thus defines satisfaction as "The judgment that a product or service feature, or product or service itself, has provided (or is providing) a pleasurable level of consumption related to fulfillment." These studies further adduce that satisfaction emanates from diverse sources of a brand such as customers' overall satisfaction with a brand, satisfaction with staff, and satisfaction with product, thus, quality of services is multidimensional. Chirani et al. [30] explained brand performance 
as the strength of the brand in terms of success register in the market place. According to this study, brand performance is based on two distinct parts. First, brand market performance, "which is the success of the brand on the market base on the aggregate market demand and is measured using sales levels and market share index". Secondly, "brand profitability performance, is an index of the financial share of the brand in relation with the retailing profits and measured on index such as profit and the profit market." For the purpose of this study, attention will be made to brand market performance in view of customers' overall brand image and intention to switch.

Additionally, Keller [5] described brand performance "on how well the product or service meets customers more functional needs." He further explained the brand performance on "how well does the brand rate on objective assessments of quality? To what extent does the brand satisfy utilitarian, esthetic, and economic customer needs and wants in the product or services category?" Therefore, quality of service includes the brand's functional performance and the emotional benefits [5] and factors that enhance a brand's promise [31] such as employees and managers during conception and delivery of the brand. Quality of services in financial services depends on customer satisfaction of service, loyalty and overall reputation of the service performance of a bank. This study further argues that, quality of services in financial service encourages willingness to pay premium price, promotes frequent use of service and giving positive word of mouth.

If brand is the basis of customer loyalty, then, quality of service is crucial to retention. Brand performance is the foundation for higher brand equity and good image. Therefore, building strong brand performance provides high returns on investment [32]. Many factors are responsible for delivering the right brand performance in financial services such as the overall service quality, trust and communication [11]. Managing these critical contact points is crucial in the overall customer experience. Keller [5] has identified brand performance at the heart of brand equity. He further stressed that a brand is produced for a purpose, to satisfy a need or want, offered to deliver on that promise, communicated through advertising, and consequently customers buy the brand based on such perceived benefits it promises. However, if, for one reason or the other the brand falls short or fail to deliver its core function, leads to customers' dissatisfaction [3]. Therefore, when brand fail on its core promise, the resultant effect is negative word-of-mouth, mostly, a cause of defection and low level of equity. Same study further noted that poor brand performance may not constitute the cause of defection among certain loyal customers and category.

According to Aaker [12], brands have relationship with customers, like one between people. Such relationships are built with brand purely based on functional benefits of the brand (such as price, quality of services). In order to minimize customer's dissatisfaction resulting in negative response, enhance service effectiveness, efficiency and empathy are central in overall brand performance $[3,5]$. According to several scientific literatures, poor service quality constitutes a fundamental reason for customer dissatisfaction [3,4]. However, it is not unanimous as to whether such dissatisfaction is ensued by customer's growing intention to switch brands.

According to the researcher's assumption, when the brand's performance or quality of service increases or meets customer's expectation, there will be a lower frequency of brand switching intention across all customer segments. Keller [2] demonstrates that increased brand performance especially in terms of its functional and symbolic attributes, helps companies to keep their customers happier and thus increases customer loyalty over a longer period of time. Also, a marginal decrease in service quality has the potential to increase the frequency of switching banks [6]. Therefore, a better brand performance or quality of service is a fundamental source for building higher brand loyalty and positive brand image [32]. However, Mohsan et al. note that when customer satisfaction is derived as a result of quality brand performance then, over time performance is not a guarantee of customer retention, especially when they can get something more elsewhere (e.g., rebates, or free services). Therefore, it is not certain whether this relationship between brand performance and brand switching intention exist in the context of banking industry in The Gambia leading to the following hypothesis: H2. As customers' perception of quality of services of a bank decreases, the intention to switch to another bank increases.

Corporate image: Corporate image is what comes to mind when a corporation is mentioned or displayed. It determines how customers respond to the product offerings - as a sum of beliefs ideas, and impressions that a public has about a company. Product and services brands continue to influence customer relationship and overall brand perception [12] through enhanced corporate branding. Such perceptions of a brand can be form, although through over time, through several means of company based associations [5]. Aaker [12] posits that consumers conceived the brand through the company (including its personnel, organization values, and programs) and other attributes that lie behind the brand.

In the extant literature, the organizational image association or company brand association [13] are used to conceptualize the company-wide associations intended to identify customer perception of the brand and the company that delivers it. According to Brown and Dacin [33] corporate association can be categorized into corporate abilities associations (associations that relate to the company's capability in producing and delivering the brand) and corporate social responsibilities associations (relates to the company's status and activities with respect to its perceived societal obligations).

Corporate-image association as a generic term is been used to describe all information a consumer holds as perceptions, beliefs, moods, emotions, and inferences about a company and its perceived attributes. Furthermore, corporate image has two principal components: functional and emotional components. Functional components relates to those factors that are tangible and measurable, while emotional component relates to psychological dimensions that can be manifested by attitudes and feelings towards an organization and its offerings.

Brown and Dacin [33] demonstrate that customers acquire associations of a company from variety of sources such as employees, media reports, technological innovation and others. Customers used these associations to relate to the organization physical and visible to them rather than the intangible services with little physics or atmospherics [12]. Company image associations constitute an integral part of the customers' experience of the company aside from the actual product and service. Apparently, there is limited empirical study on the impact of corporate image associations on customer decision to switch. However, Brown and Dacin [33] showed that corporate image association has different influence on customers' perception of a brand. Adding that, corporate ability associations (such as technological innovation, word-of mouth communication) and corporate social responsibilities associations (such as community involvements, sponsorship of cultural activities) affect customers' reactions to the company and its products and services. 
However, the companies that are associated with negative perceptions and customer beliefs may not invoke similar negative responses to the company and its brand [33]. Therefore, perceptions may vary significantly among different customer segments and markets. To enhance customer-brand trust, strategic corporate branding is required at the heart of the process. Hatch and Schultz further noted that corporate branding promotes the overall company's relationship with customers and employees; hence employees reciprocate by enhancing brand citizenship. Also, Cheng et al. added that through corporate branding, employees can create symbolic meaning in their interaction with customers and help influence the customer-brand relationship, it can be assumed that when customers have a favorable perception of a bank's overall image, it will therefore increase customer attraction and reduce defection. Brown and Dacin [33] note that customers reinforce their purchase intention for brands produced by companies with positive associations (such as corporate social responsibilities and distinct corporate abilities). This could be attributed to the fact that the company plays vital roles to the community through CSR initiatives. Flavian et al. [34] posits that there is a relationship between corporate image and purchase intent and increases significantly as customer maintains relationship with a bank. However, this is not clear whether there exists congruence between corporate image and bank switching hence the following hypothesis is used: H4. When consumers develop an increased good image of a bank, the intention to switch to another bank decreases.

Celebrity endorsement: Celebrity endorsement has gain popular attention in advertising scene in both product category and services sector. According to Keller [5], celebrity endorsements is the use of famous and more prominent personalities to influence customers' perception of the brand, based on the belief that fans of such celebrity will transfer similar favorable image to the product or services. Creating a favorable brand image is a fundamental endeavor to enhance strong brand equity [1]. There is an increase use of celebrities to create a more favorable brand image by reflecting on special or unique characteristics, and prestige to the customers. Celebrities are used as spokespersons to deliver advertising messages to persuade, and influence customer perception of the brand [35]. Celebrity endorsement alone may not guarantee any significant influence in behavior, but using different customer psyche and well planned advertising campaign can go a long way in changing and reshaping customer mindset [36].

In many countries such as The Gambia, Celebrities are not only admired but worship - giving them great influence in our purchase decision making. If celebrity endorsement is successful, then the brand's sales increase [37]. Studies further showed that celebrity endorsement influence the customer's purchase decision, and promotes the overall image and corporate loyalty in the market [38]. Aaker [12] identifies the following important measures of celebrity: celebrity trustworthiness, celebrity expertise, celebrity attractiveness.

Assumption can be made that using highly favorite celebrity in marketing campaign could increase trust and reduce the frequency of brand switching among all customer segments. It is because celebrities often admired, has the tendency to influence customer purchase intention, and if successful, can cause defection from one brand to another [37]. Dzisah and Ocloo [36] note that different customers respond differently towards celebrity campaign, for example, women and the less educated respond more easily to celebrity adverts. Although is not clear whether there exists a relationship between celebrity endorsement and brand switching, thus using the following hypothesis: H3. As customers develop positive image of celebrities in advertising campaigns of a bank, the intention to switch to another bank decreases.

Consumer trust: In today's competitive environment, businesses that practice customer oriented marketing see the necessity to deliver service quality for the first time and stimulate customer relationship that builds brand equity. These among other practices enhance good business conduct. It demonstrates the extent to which a company delivers that which it promises. Therefore, customer trust building is an integral part of profitable client relationship that enhances brand loyalty [3]. Studies opined that trust is the reason for which customers build upon purchase decision making, and influence the quality of the interaction and commitment of the client to the relationship [39].

Customer trust is defined as the confidence that one has in the service provider built based on the provider's reliability and integrity [40]. Furthermore, this study argues that trust is a behavioral intention of 'willingness' and where one believes that the provider is trustworthy without being ready to rely on that partner, then trust is limited.

Coulter and Coulter [41], posits that consumer trust can emerge from repeated interactions with increased length of relationship. When there is lack of trust for a company among consumers, the success and profitability is unsecured. According to studies, several factors help companies build a lasting customer trust and commitment: shared value, communication and relationship [40], offered complementary factors (competence, customization, reliability, performance) and people-related aspects (empathy, politeness, similarity) promotes company's trustworthiness among consumers [41].

It can be assumed that when customers developed a mutual trust with the business, they are likely to remain loyal as the relationship develops from traditional buyer-seller relationship to that of a more beneficial and supportive one between parties. Ebert [42] note that trust facilitates both consumer loyalty and customer retention, but also compensates for information asymmetries, reduces transaction costs, and lowers perceived risk. Also adds that as much as trust influencies consumers purchase intention, trust immensely impacts organizational overall performance and competitiveness. Furthermore, customers trusting beliefs and willingness to depend on a service provider both strongly affect specific behavioral intentions, and willingness to follow advice, share information, and purchase [43]. According to this study, consumer trusting beliefs reflect perceptions about the service provider (in terms of competence, benevolence, integrity), while willingness to depend reflects a general attitude to move the relationship with the provider forward by willing to become vulnerable to the provider. Mavri and Ioannou [44] note that influence of trust differs in terms of intensity and among different group of consumers. Using these assertions, the following hypothesis suggests that when customer's trust in a service provider is strengthened, there is less likely for defection by the customer holding other factors constant 'ceteris paribus.' hence H5. The more customers' trust in a bank increase, the intention to switch to another bank decreases.

Customer satisfaction: Customer satisfaction and customer retention in strategy formation help to enhance the practice of customer focus and increase customer based brand equity. According to many studies, customer satisfaction is treated as a dependent variable which aimed at value creation and enhanced by committed relationship with clients $[45,46]$. According to Selnes [47] customer satisfaction is derived when value is improved by adding the benefit or reducing the cost to the buyer. When customer make purchase decision, they consider many value criteria, thus it is imperative that when one or 
more of these criteria are met then satisfaction is ensured and this leads to repurchase behavior or loyalty.

Jamal and Naser [45] suggest that customer satisfaction can be measured by the overall service quality, meeting expectation, and satisfaction with services. Therefore, customer satisfaction is multidimensional construct; hence it can be measured using multiple interactions. Several factors are responsible for customer satisfaction such as the core and relational aspect of overall service quality, and the tangible cues such as staff, technology, and physical environment where service is delivery takes place [45]. These factors vary in influence among expert customers and novice customers, requiring service providers a foreknowledge of its customers prior, during, and after service performance. On the other hand, poor service quality significantly leads to drop in customer satisfaction, willingness to recommend to a friend and conversely increase consumer intention to switch to alternative brand elsewhere [46]. This study further posits service recovery is essential for customers who had experienced poor service quality.

Based on several literature, customers prefer to switch to other businesses and the reasons may not be associated to how satisfied are customers but rather perceived level of satisfaction [45,46]. Customer satisfaction is not limited to service quality, but rather core and relational performance, problem encountered and satisfaction with problem recovery (Levesque and McDougall. Thus, this factor may have different level of influence among different customers. This hypothesis proposed that customer's perception of satisfaction may influence their intention to switch from one bank to another, hence the following hypothesis: H6: The more satisfied customers are with a bank, the less likely they will switch to another bank.

\section{Research Design and Method}

\section{Defining measurement scales}

Measurement scales consist of questions defined by hypothesis used to collect the required data for the study. Seven (7) constructs are used in this study namely: price, quality of service, celebrity endorsement, corporate image, trust, satisfaction, and switching intention. All the constructs used in the study were measured according to Likert seven (7) point scale from strongly disagree to strongly agree. The internal reliability Cronbach's Alpha test was performed using the IBM SPSS statistics (version 22), thus giving the values of Cronbach's alphas ranging from 0.79 to 0.93 for all the constructs used in this study. Reliability of all the scales is adequate and internally reliable for this study.

\section{Sampling and data collection techniques}

In this study, the researcher uses a combination of both primary and secondary source of information as backdrop to this research process. According to Joseph et al., a multi-method mode of data collection ensures the extrapolation of significant population size and enhances generalization of results to a wide category of respondents. The primary sources involved the collection of the empirical data direct from the consumers of commercial banks in The Gambia. Secondary collection mode was also conducted and helps researcher to draw on the already existing literature found on the related topic thus providing the basic understanding of the theoretical background of the topic. The study employed a self-administered questionnaire via online as a form of data collection instrument. The researcher designs and delivered to the respondents that constitute a selected group of customers in The Gambia with invitation to participate in the survey. E-mail and other social media platforms (such as Facebook, Twitter, and LinkedIn) were used to contact respondents, follow-ups and response submission. The poor mailing systems, bad internet connection, and personal privacy issues of banking necessitate the use of online survey questionnaire as media for data collection.

Convenient sample sizes of two hundred and ten (210) respondents were involved in this study to represent a cross section of the private banking clients in The Gambia. According to Central Bank of The Gambia (2014), the banking population constitute about less than $60 \%$ of the country's population of 1.8 million as at 2012 . Out of which $40 \%$ are individual retail banking clients. The survey includes customers who are currently banking with at least one of the commercial banks in the country. With this sampling technique, a significant amount of accepted responses is guaranteed with less cost, time, and high response rate, thus reducing the non-response error.

The respondents in the study consist of mainly customers who are having a banking relation with one of the selected banks over the past seven years. Interested respondents were contacted through email and other social media (such as Facebook, Twitter, and LinkedIn) to submit their emails if they are willing to participate in the survey.

\section{Data Analysis}

\section{Sample profile}

The purpose of the study is to identify how consumer brand knowledge or associations with commercial banks in The Gambia affect customers' intention to switch. Invitations were sent out to several people to participate in the survey. The survey was conducted in The Gambia. E-mail and social media platforms such as Facebook, Twitter and LinkedIn were employed in order to reach out to respondents. Out of three hundred (300) invitations sent out, a total of two hundred and ten (210) complete questionnaires were returned and constitute the total number of responses for this survey. Of all the number of respondents (39\%) are Female and (61\%) constitutes Male. The average respondents between 20 to 30 years of age were (68\%). Age category between 31 to 45 years was (31\%) and those from 46 years and above make up a total of (8.6\%) respondents. A significant percent of (69.9\%) of respondents have acquired Graduate/post-graduate level of education. Up to (24.8\%) of the total respondents have acquired College/Professional level of education and those with Lower/secondary education make up of (13.3\%) of total respondents. Up to (25.2\%) of total respondents says they received monthly income of GMB 15,000 and above, while a total of (35\%) received monthly income between GMB 5,000 to GMB 10,000. A total of (21.9\%) respondents report a monthly income between GMB 10,000 to GMB 15,000. Only (17\%) respondents say they received monthly income of less than GMB 5,000. Note: Exchange rate of Gambian Dalasi into Euro is GMB 44.78=1 Euro (Central Bank of The Gambia, 18/12/2016).

\section{Descriptive statistics}

All the constructs used in this study were measured according to Likert seven (7) point scale ranging from strongly disagree to strongly agree. Descriptive statistics of frequency of constructs showed that there are different opinions of respondents in terms of responses to each construct. The Mean ( $\mathrm{m}$ ) of the constructs showed that respondents are more inclined to neutral tendencies (i.e., 4.5) in their overall evaluation price and celebrity endorsement, thus, Price perception $(\mathrm{m}=4.36)$, and Celebrity endorsement $(m=3.94)$. However, Trust $(m=5.02)$, Satisfaction $(\mathrm{m}=4.81)$, Quality of service $(\mathrm{m}=4.68)$, and Corporate 
image $(m=4.62)$ received much higher evaluation towards positive tendencies among respondents.

\section{Research findings}

Respondents had different opinion about selected brand association or experience with the bank (regarding price, quality of services, celebrity endorsement, corporate image, trust, and satisfaction) and influence differently on their intention to switch banks. Testing $\mathrm{H} 1$, a bivariate correlation was conducted $(r=-0.379, p>0.001)$ and thus results showed that there is significant negative correlation between price perception and customer intention to switch from one to another. Based on this evidence, $\mathrm{H} 1$ is confirmed. Correlation statistics was conducted to test $\mathrm{H} 2$. The result shows that there is a significant negative relationship between quality of services and customer intention to switch $(r=-$ $0.459, \mathrm{p}>0.001$ ), thus $\mathrm{H} 2$ is confirmed. Furthermore, $\mathrm{H} 3$ was test using correlation and the result shows that is no significant relationship between consumer perception of celebrity endorsement and their intention to switch banks, hence ( $r=-0.087, \mathrm{p}>0.05)$. This means that celebrity endorsements in advertising campaigns of a bank have no significant influence in customer's intention to switch banks. Based on this evidence $\mathrm{H} 3$ is rejected. Testing the correlation between customer opinion of an overall corporate image and intention to switch banks, result shows that there is a significant negative correlation between the factors ( $\mathrm{r}=-0.436, \mathrm{p}<0.001)$. According to this result, increased positive image or good image of a bank decreases consumer intention to switch from one bank to another at a particular time. Based on this evidence, $\mathrm{H} 4$ is confirmed. Furthermore there is a strong correlation between consumers' trust in a bank and their intention to switch to another bank, hence $(r=-0.511, p<0.001)$. Meaning, when consumers trust and confidence in a bank increases, the less likely they will intent to switch to other banks less trustworthy. Based on this evidence, H5 is confirmed. To validate H6, correlation test shows that there is a significant negative relation between customer satisfaction and intention to switch banks $(\mathrm{r}=-0.517, \mathrm{p}>0.001)$. According to this statistics, increased customer satisfaction by a bank, reduces the tendency to develop bank switching intention among respondents less likely in The Gambia. Therefore, H6 is confirmed.

Correlation between customer opinion of different brand associations - and switching intention.

Meanwhile, results of one-way ANOVA proved that some categories of consumers differ from one another in terms of switching intention. The interaction between gender and switching intention showed that there is no significant difference between male and female respondent in terms of bank switching intention, hence $f(2)=0.238$, p> 0.05. Therefore, there is no statistical significant between male and female respondents in terms of bank switching intention. Result show female respondents with $(\mathrm{m}=3.387)$, compared to their male counterparts $(\mathrm{m}=3.273)$. Table below show SPSS output of the above statistics (Table 1).

\section{Conclusions and Scientific Contribution}

Trust has been said to be the next serious business for serviceoriented businesses nowadays than it has ever been. A significant percent of respondents evaluated that when a bank becomes more trustworthy, they are more likely to stay loyal as widely confirmed in literature. Service responsiveness, commitment to customers and interactional and procedural justice are the hallmark of customer behavioral intention to trust a service provider.

Our results showed that higher level of service quality is a hallmark

\begin{tabular}{|c|c|c|}
\hline \multirow{2}{*}{ Price perception } & & Switching intention \\
\hline \multirow{2}{*}{ Quality of service } & Correlation & -0.379 \\
\cline { 2 - 3 } & Sig. (2-tailed) & 0.000 \\
\hline \multirow{2}{*}{ Celebrity endorsement } & Correlation & -0.459 \\
\cline { 2 - 3 } & Sig. (2-tailed) & 0.000 \\
\hline \multirow{2}{*}{ Satisfaction } & Correlation & -0.087 \\
\cline { 2 - 3 } & Sig. (2-tailed) & 0.208 \\
\hline \multirow{2}{*}{ Trust } & Correlation & -0.517 \\
\cline { 2 - 3 } & Sig. (2-tailed) & 0.000 \\
\hline \multirow{2}{*}{ Corporate image } & Correlation & -0.511 \\
\hline & Sig. (2-tailed) & 0.000 \\
\hline & Correlation & -0.436 \\
\cline { 2 - 3 } & Sig. (2-tailed) & 0.000 \\
\hline
\end{tabular}

Table 1: SPSS output of the above statistics.

for reduced customer switching intentions associated with poor quality of service and service failure. Therefore, banks should ensure that service quality and performance dimensions such as reliability and friendliness of service personnel, timeliness, privacy, security of domestic and international transactions, and core value propositions are operational to curb the increase in bank switching and promote loyalty.

Results showed that corporate image is third most important factor that influences customer's decision to switch banks. Corporate image serves as a visible element of an organization and help customers evaluation of future performance. A good reputation of organization helps to increase sales and exploits profitable marketing opportunities. In order to achieve this, banks must monitor all brand touch points both nation and international, and all communications to maintain the reputation of the bank and its national brand at the highest level in order to promote customer acquisition and retention.

Several researches confirm that there is a strong negative relation between prices and switching. However, for the purpose of this study the relationship tends to be a weak one and though supports that price perception is a significant influence in consumer bank switching intention. The question is why this is the case? Simply, it can be argue that bank's pricing in The Gambia is highly sensitive to competition, and tough regulations enforced by the Central bank through its monetary and fiscal policies. Additionally, Gambia is composed of more that $90 \%$ Muslims among which a significant per cent is not receptive to interest rates on deposits and interests levy on bank credits (loan/overdraft facilities). For such group of consumers, a high interest on deposits is a disincentive and could result to bank switching intention. Customers must be advised prior to services, whether they are interested in bank interest on deposits in order to avoid or minimize dissatisfaction associated with interest payments. Also, new banking services that are purely "halal" (acceptable according to Islamic banking etiquettes) may be introduced to attract this segment of the market. Gambia is among the least developing countries of the world with a GDP per capita $\$ 528.79$ (CBG, 2014). Thus, bank's pricing must be affordable at the same time profitable for both the bank and its consumers.

\section{References}

1. Aaker DA (1991) Managing Brand Equity Capitalizing on the Value of a Brand Name. New York, The Free Press.

2. Keller L (2008) Strategic Brand Management, Building, Measuring and Managing Brand Equity. (3rd Edn.), Pearson Education, Upper Saddle River, NJ.

3. Berry $L$ (2000) Cultivating service brand equity. Journal of the Academy of Marketing Science 28: 128-137. 
4. de Chernatony L, Harris $\mathrm{FH}(2000)$ The challenge of financial services branding: majoring on category or brand values. Open University Business School, UK.

5. Keller L (2003) Strategic Brand Management: Building, Measuring and Managing Brand Equity. Pearson Education, Upper Saddle River, NJ.

6. Clemes MD, Gan C, Zheng LY (2007) Customer switching behavior in the New Zealand banking industry. Banks and Bank Systems 2: 50-65.

7. Kapferer JN (2008) New strategic brand management: creating and sustaining brand equity long term, new exciting ideas and perspectives on brand building.

8. Ergin EA, Özdemir H, Özsaçmacı B (2006) The Effect of Brand Associations: A Field Study on Turkish. Consumers International Business \& Economics Research Journal 5: 65-74

9. Del Rio B, vaâzque R, Iglesia $V(2004)$ The effects of brand associations on consumer response. Journal of Consumer Marketing 18: 410-425.

10. Korchia M (2004) The effects of brand associations on three constructs. Proceeding from the 33rd EMAC Conference, Murcia, Spain, May.

11. Ghantous N, Phan KN (2013) Managing brand associations to drive customers trust and loyalty in Vietnamese banking. International Journal of Bank Marketing 31: $456-480$

12. Aaker DA (1996) Building Strong Brands. Free Press: New York.

13. Keller KL (1993) Conceptualizing, measuring and managing Consumer Based Brand Equity. Journal of marketing 57: 1-29

14. Romaniuk J, Thiel MN (2011) Behavioral brand loyalty and consumer brand associations.

15. Supphellen M (2000) Understanding core brand equity: Guidelines for in-depth elicitation of brand associations. 'International journal of market Research.

16. Keller KL (1999) Brand Mantras: Rationale, Criteria and Examples. Journal of Marketing Management 15: 43-51.

17. Ballester ED, Espallardo MH (2008) Effect of Brand Associations on Consume Reactions to Unknown On-Line Brands. International Journal of Electronic Commerce 12: 81-113.

18. Romaniuk J, Sharp B (2004) Conceptualizing and measuring brand salience. Marketing Theory 4: 327-342.

19. Chinomona R, Mahlangu D, Pooe D (2013) Brand Service Quality, Satisfaction, Trust and Preference as Predictors of Consumer Brand Loyalty in the Retailing Industry. Mediterranean Journal of Social Sciences 4: 181-190.

20. Maghzi A, Abbaspour B, Eskandarian M, Hamid AB (2011) Brand Trust in Hotel Industry: Influence of Service Quality and Customer Satisfaction. 2nd International Conference on Business, Economics and Tourism Management 24: 42-46.

21. Colgate M, Hedge R (2001) An investigation into the switching process in retail banking services. International Journal of Bank Marketing 19: 201-212.

22. Keaveney SM, Parthasarathy M (1995) Customer switching behavior in services industry: An exploratory study of the role of selected attitudinal, behavioral, and demographic factors. Journal of Marketing 29: 374.

23. Ghouri AM, Siddqui UA, Shaikh A, Alam I (2010) Determinants Analysis of Customer Switching Behavior in Private Banking Sector of Pakistan. Institute of Interdisciplinary Business Research 2: 96-110.

24. Gerrard P, Cunningham JB (2000) The bank switching behavior of Singapore's graduates. Journal of Financial Services Marketing 5: 118-128.

25. Farquhar JD, Panther T (2008) Acquiring and retaining customers in UK banks An exploratory study. Journal of Retailing and Consumer Services 15: 9-21.

26. Zeb H, Rashid K, Javeed MB (2011) Influence of Brands on Female Consumers' Buying Behavior in Pakistan. International Journal of Trade, Economics and Finance 2: 225-231.

27. Nguyen TH, Gizaw A (2014) Factors that influence consumers purchasing decision of private label Food product: A case study of ICA Basic. School of Business, Society and Engineering, pp: 1-84

28. Manrai LA, Manrai AK (2007) Business-Society Relationship. Proceedings of the International Association for Business and Society 18: 218-221.

29. de Chernatony L, Harris FJ (2001b) Measuring the consumer-based equity of financial services brands. Journal of Marketing Science 14: 85-132.
30. Chirani E, Taleghani M, Moghadam NE (2012) Brand Performance and Brand Equity. Interdisciplinary Journal of Contemporary Research in Business 3 : 1033-1036.

31. de Chernatony L, Harris FH (2001a) Corporate branding and corporate brand performance. European Journal of Marketing 35: 441-456.

32. Ahmad N, Iqbal N (2013) The Impact of Market Orientation and Brand Orientation on Strengthening Brand Performance: An insight from the Beverage industry of Pakistan. International Review of Management and Business Research 2: 128-132.

33. Brown TJ, Dacin PA (1997) The Company and the Product: Corporate Associations and Consumer Product Responses. Journal of Marketing 61: 6884.

34. Flavian C, Guinalin M, Torres E (2005) Influence of corporate image on consumer trust: A comparative analysis in tradition vs internet banking. Internet research 15: 447-470.

35. Dash SK, Sabat DR (2012) The impact of Celebrity endorsed TV commercials on demographic dynamics of attitude: An Indian Context. International Journal of Research in Management \& Technology 2: 192-204.

36. Dzisah WE, Ocloo CE (2013) Celebrity Endorsement and Consumer Buying Behavior; Enhancing the Promotion Function of Marketing in the Central Business Area of Accra. Journal of consumer behavior and sciences.

37. Hassan SR, Jamil RA (2014) Influence of Celebrity Endorsement on Consumer Purchase Intention for Existing Products: A Comparative Study. Journal of Management Info 4: 1-23.

38. Hoseinzadehshahri M, Ebrahimi M (2015) Effect of Celebrity Endorsement on Consumer's Perception of Corporate Image, Corporate Credibility and Corporate Loyalty (Case Study: Novin Charm Company). Case Studies in Business and Management 2: 51-67.

39. Gill AS, Flaschner AB, Shachar M (2006) Trust influence. International Journal of Bank Marketing.

40. Morgan RM, Hunt SD (1994) The commitment- trust theory of relationship marketing. Journal of marketing 58: 20-38.

41. Coulter KS, Coulter RA (2000) Determinants of trust in service provider: the moderating role of length of relationship. Journal of Service Marketing 16: 35-50.

42. Ebert T (2009) Trust as the Key to Loyalty in Business-to-Consumer Exchanges: Trust Building Measures in the Banking Industry. Springer Science \& Business Media, pp: 198.

43. McKnighta HD, Choudhuryb V, Kacmarc C (2002) The impact of initia consumer trust on intentions to transact with a web site: a trust building model. Journal of Strategic Information Systems 11: 297-323.

44. Mavri M, loannou G (2008) Customer switching behaviour in Greek banking services using survival analysis. Managerial Finance 34: 186-197.

45. Jamal A, Naser K (2002) Customer satisfaction and retail banking: an assessment of some of the key antecedents of customer satisfaction in retail banking. International Journal of Bank Marketing 20: 146-160.

46. Levesque T, McDougall GHG (1996) Determinants of customer satisfaction in retail banking. International Journal of Bank marketing 14: 12-20.

47. Selnes $F$ (1993) An examination of the effect of product performance on brand reputation, satisfaction and loyalty. European Journal of Marketing 27: 19-35. 